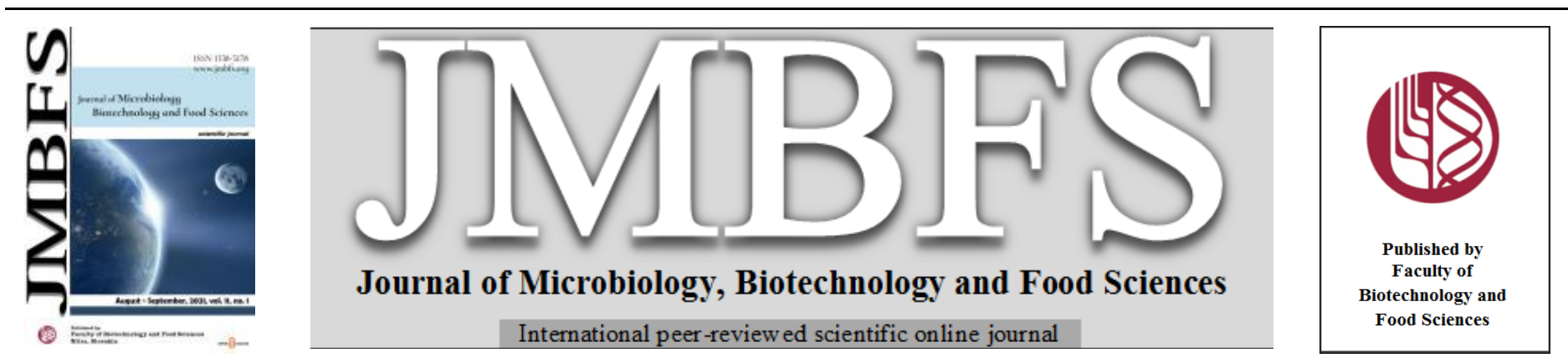

\title{
BIO-PROFILING OF A POTENTIAL ANTIMYCOBACTERIAL BACTERIOCIN PRODUCED BY BACILLUS SUBTILIS (MK733983) OF ETHNOMEDICINAL ORIGIN
}

\author{
Santhi Sudha S. ${ }^{1}$, Aranganathan V. *2
}

Address(es): Aranganathan V

${ }^{1}$ Jain (Deemed to-be-University, Doctoral Research Scholar, Department of Biochemistry, 18, 3rd Block, 9th Main Rd, Jayanagar, Bengaluru, Karnataka 560011. Phone: +919035501749, 08043226500 .

${ }^{2}$ Jain (Deemed to-be-University, Faculty, Department of Biochemistry, 18, 3rd Block, 9th Main Rd, Jayanagar, Bengaluru, Karnataka 560011. Phone: +919035501749 , 08043226500 .

*Corresponding author: v.aranganathan@jainuniversity.ac.in

https://doi.org/10.15414/jmbfs.3259

\section{ARTICLE INFO}

Received 12. 6. 2020

Revised 8. 3. 2021

Accepted 10. 3. 2021

Published 1. 8. 2021

Regular article

OPEN $\partial_{\text {ACCESS }}$

\begin{abstract}
Antibiotic resistance is a global crisis and antimicrobial peptides or bacteriocins are the ascending alternatives. This study is reporting a potential bacteriocin from B. subtilis (MK733983) of ethnomedicinal origin showing significant activity with Mycobacterium smegmatis as an indicator organism on spot-on-lawn assay. Production optimization with suitable physical parameters such as modified lysogeny broth $\left[1.5 \%\right.$ peptone; $0.75 \%$ salt; $0.75 \%$ yeast], temperature $\left[35^{\circ} \mathrm{C}\right], \mathrm{pH}[7]$, inoculum size $[1 \%]$ and time course $[24 \mathrm{~h}]$ has enhanced the activity up to $20 \%$. This study also observed that supplements like minimal essential medium amino acids and B complex vitamins individually has further enhanced the bacteriocin activity by $13 \%$ (total $33 \%$ ), biomass by $43 \%$, total protein and activity by $17 \%$ and $22 \%$ respectively. However, addition of some common growth supplements like multivitamins with trace elements, $\mathrm{CaCl}_{2}$ and $\mathrm{MgSO}_{4}$ had shown inhibitory effect on bacteriocin activity. Molecular weight of the bacteriocin was estimated to be below 14kDa and bioassay guided TLC techniques showed distinctive antibacterial activity. The bacteriocin completely lost its activity with Trypsin, $\alpha$ Chymotrypsin, Proteinase K but not with Amylase, and showed up to $40 \%$ activity with Papain. It showed heat stability up to $70^{\circ} \mathrm{C}$ with a wide antibacterial spectrum against standard strains of Staphylococcus aureus, Pseudomonas aeruginosa, Klebsiella pneumoniae, Escherichia coli and Chromobacterium violaceum with minimal inhibitory concentrations ranging between $0.325 \pm 0.02$ $0.75 \pm 0.02 \mathrm{mg} / \mathrm{mL}$, suggesting the bacteriocin may have wide application prospects.
\end{abstract}

Keywords: Bacteriocin; Bacillus subtilis; Ethnomedicinal origin; Bioassay guided TLC techniques; wide antibacterial spectrum

\section{INTRODUCTION}

Antimicrobial resistance (AMR) has become an escalating global burden with an increase in the microbial resistance endangering the efficacy of antibiotics across all socio-economic backgrounds, with other complicated risks such as drug-drug interactions, hospital acquired infections and others posing a serious challenge (Ventola, 2017). Although campaigning on minimization of antibiotic prescriptions, encouragement of antibiotic-free food industry, minimizing antibiotic use in meat industry and chemical preservatives, and novel diagnostics with generation of antimicrobial agents are in progress, the development of new antimicrobials has declined in recent years. One of the tangible reasons is due to its production cost and the complexity of the multiple resistance mechanisms developed by the AMR microbes and thus, development of potential antimicrobial agents has become very difficult and a critical priority in the present world (Lopez et al., 2017; WHO report, 2017).

Antimicrobial peptides (AMPs) also known as host defensive proteins (HDPs) seem to be promising alternatives to traditional antibiotics, antiseptics, and other non-specific anti-bacterial substances due to their high potency, specific antibacterial spectrum, low risk of resistance development, limited effects on the normal flora and importantly, they can be chemically modified to more efficient forms (Christopher et al., 2012). Some bacterial species produce biologically active proteins or peptides known as peptide antibiotics, also known as bacteriocins (Zhang et al., 2018). Many of these ribosomally synthesized peptides or proteins are known to have narrow spectrum, inhibiting the bacteria that are taxonomically close, but a few others are known to be broad spectrum (Silva et al., 2018). Even further ahead, bacteriocins were reported to have inhibited polymicrobial infections (Ramya et al., 2014), capable of inhibiting biofilm formation (Khalaf et al., 2016) and a few studies have shown to inhibit taxonomically unrelated bacteria and certain viruses (Park et al., 2002). Although the productivity of bacteriocins by microbes like bacteria are time consuming with below par yield, these challenges can be compensated with an effective optimization and purification techniques. Furthermore, characterization of the biologically active compounds like bacteriocins is pivotal for comprehensive understanding of their scope in their future potential as therapeutic agents, preservatives, or other uses.

Present study was focused on optimizing B. subtilis (MK733983) strain capable of producing a potential antimycobacterial bacteriocin with $M$. smegmatis as an indicator microorganism (IMO). Purification by solid phase extraction of the bacteriocin, molecular weight determination, characterization with hydrolytic enzymes and organic solvents were delineated. The active compounds were also characterized by bioassay guided chromatographic (TLC) techniques for detecting antimicrobial activity under diverse occurrences (Mahmoud et al., 2018). Antibacterial Inhibition spectrum of the bacteriocin was tested against some standard strains of gram positive and negative bacteria that fall under WHO critical and high priority pathogen list (WHO report, 2017).

\section{MATERIAL AND METHODS}

\section{Indicator microorganisms and culture conditions}

Indicator microorganisms (IMO's) were taken in inoculum size of $10^{6} \mathrm{CFU} / \mathrm{mL}$ cells measured at $\mathrm{A}_{600}$ for all the antimicrobial assays under prescribed suitable growth conditions. Standard bacterial strains of M. smegmatis (MC ${ }^{2}-155$ wild type), S. aureus (MTCC 737), P. aeruginosa (MTCC 3541) and C. violaceum (MTCC 2656) were cultured using LB (Luria-Bertani) media, and $K$. pneumoniae (ATCC 700721), E. coli (ATCC 8739) were cultured using Muller-Hinton Media at $35^{\circ} \mathrm{C}$ for $24 \mathrm{~h}$.

\section{Bacteriocin Production Optimization}

Standard LB media for the isolated B. subtilis (MK733983) was optimized by one-factor optimization method for maximum bacteriocin production using 
carbon, nitrogen and salt concentrations, along with other biophysical parameters like $\mathrm{pH}$ (6.0-8.5 with interval of 0.5$)$; Inoculum size (1-6\%); temperature (20$50^{\circ} \mathrm{C}$ with interval of $5^{\circ} \mathrm{C}$ ) and effect of time course on growth along with the bacteriocin production was studied by measuring the colony forming units $(\mathrm{CFU} / \mathrm{mL})$ at $\mathrm{A}_{600}$ up to 5 days. The bacteriocin preparation is described in detail by Santhi \& Aranganathan (2019) and production optimization was determined step-by-step, advancing to next parameter with already optimal factors and their bacteriocin activity was determined by $30 \mu \mathrm{L}$ of each of bacteriocin $(1 \mathrm{mg} / \mathrm{mL})$ loaded into $6 \mathrm{~mm}$ wide wells made in LB agar plates pre-swabbed with $100 \mu \mathrm{L}$ of M. smegmatis $\left(10^{6} \mathrm{CFU} / \mathrm{mL}\right)$ as an indicator and zone of inhibition (ZOI) in $\mathrm{mm}$ was taken as a measure of antimicrobial activity (Tagg \& McGiven, 1971). The bacteriocin producer was further optimized with supplements like minimal essential medium (MEM) amino acids (1-2\%), Multivitamins and B complex vitamins $(0.5-2 \%), \mathrm{CaCl}_{2}$ and $\mathrm{MgSO}_{4}(0.1-0.5 \mathrm{~g} / \mathrm{mol})$. For testing the growth kinetic pattern of $B$. subtilis (MK733983), its culture could grow with the delineated optimal parameters, simultaneously, the bioactivity of its supernatant was assessed by optical density values measured spectrophotometrically at 600 $\mathrm{nm}$. Their supernatants were collected at a regular time interval of $3 \mathrm{~h}$, was used for preparing bacteriocin concentrate $(1 \mathrm{mg} / \mathrm{mL})$. It was then checked for its antimicrobial activity through well diffusion assay with $M$. smegmatis as the indicator by taking each of $30 \mu \mathrm{L}$ per well $(6 \mathrm{~mm})$, this experiment was done twice in triplicates. All chemicals were purchased from SD Fine-Chem Ltd (India) and Himedia for all the experiments in the entire study.

\section{Solid Phase Extraction}

The bacteriocin obtained from optimized media was ultra-filtered with Polyether sulfone membrane syringe filter - pore size $0.22 \mathrm{~mm}$ (Merck) and then loaded to a C18 Sep-Pak cartridge (Flinn Scientific) that was thoroughly pre-washed with double distilled water, followed by the bacteriocin loading and was eluted with $100 \%$ methanol as an attempt for initial purification step. The eluted sample was further concentrated by drying in a hot air oven $\left(45^{\circ} \mathrm{C}\right)$ and were dissolved in DMSO [Dimethyl sulfoxide] and was used for further study on antimicrobial assays, with $M$. smegmatis $\left(10^{6} \mathrm{CFU} / \mathrm{mL}\right)$ as an indicator.

Bacteriocin activity was defined as the reciprocal of the highest dilution at which bacterial growth was inhibited and expressed as arbitrary units (AU) per milliliter. Activity was calculated as $\mathrm{a}^{\mathrm{b}} \times 100$, where $\mathrm{a}$ is the dilution factor and $\mathrm{b}$ is the final dilution factor that can produce minimum inhibition zone $(2 \mathrm{~mm})$ and the experiments were done in quadruplicates. The increase in yield optimization and purification was evaluated by Lowry's protein estimation (Lowry et al., 1951), bacteriocin specific activity (Lee $\boldsymbol{e t}$ al., 2018) and bacteriocin activity by spot on lawn method.

\section{Characterization of bacteriocin}

\section{Molecular weight determination}

Molecular mass determination was done by tricine-Sodium dodecyl sulfate polyacrylamide gel electrophoresis (SDS-PAGE) 5\% stacking and $12 \%$ separating gels (Schagger \& Jagow, 1987). Electrophoresis was run with midrange marker [SRL protein marker, mid-range cat BCL - 038 (14.3-97.4)] and it was carried out at $50 \mathrm{~V}$ for first half an hour followed by $100 \mathrm{~V}$. Since many bacteriocins are known to be sensitive to different stains, the gels were stained with widely used Coomassie brilliant blue (CBB) and Silver nitrate. One set of the gels were left in a fixative solution (50\% methanol; $10 \%$ acetic acid) for 30min, followed by CBB (R)-250 staining overnight. Then gels were de-stained with $10 \%$ acetic acid and $20 \%$ methanol.

Another set of gels were stained by silver-stain by washing thoroughly in $50 \mathrm{mM}$ (NH4)2HCO3 in 50\% methanol and were then incubated in sensitizing solution $(\mathrm{Na} 2 \mathrm{~S} 2 \mathrm{O} 3.5 \mathrm{H} 2 \mathrm{O} \mathrm{w} / \mathrm{v} 0.02 \%)$ for $2-3 \mathrm{~min}$ on gentle rotation (Giulian et al., 1983). Later, washed thoroughly with chilled sterile water and were put in staining solution $(0.2 \% \mathrm{w} / \mathrm{v}$ Silver nitrate in $0.076 \%$ formalin) and were kept under gentle rocking until the bands were visible. Once the bands were visible, the reaction was immediately stopped by adding terminating solution (12\% acetic acid) and all the results were recorded. This experiment was done twice with duplicates.

\section{Bio-Profiling}

\section{Thin Layer Chromatography-Direct Bioautography (TLC-DB)}

Demetrio et al. (2016) TLC-DB protocol was followed with minor variation, $\sim 5 \mu \mathrm{L}$ of bacteriocin $(1 \mathrm{mg} / \mathrm{mL})$ was spotted manually on to a pre-conditioned silica gel plate $(6 \times 4 \mathrm{~cm})$ (Fluka, silica gel $60 \mathrm{~F}-254)$ with organic solvents (butanol/methanol) for $30 \mathrm{~min}$ at a temperature range of $18-20^{\circ} \mathrm{C}$. The plates were dried horizontally for a few minutes at room temperature before placing them in the development chamber and was run with a predetermined, suitable mobile phase of butanol-methanol-water in 3:1:1. Later, the plate was visualized at $395-570 \mathrm{~nm}, 450-495 \mathrm{~nm}$ and $380-450 \mathrm{~nm}$ in UV TLC viewer and the relative retardation factor (Rf) was calculated. For the Direct bioautography, when TLC plate was sprayed with $5-10 \mathrm{~mL}$ of $M$. smegmatis cell suspension $\left(10^{6} \mathrm{CFU} / \mathrm{mL}\right)$ and were incubated at $37^{\circ} \mathrm{C}$ for $24 \mathrm{~h}$ and the antibacterial activity was identified as spots with clear zones of inhibition against the indicator organism. This experiment was done in triplicates.

\section{Contact Bioautography}

Khurram et al. (2009) protocol for contact bioautography was followed with a variation, where the TLC chromatogram of approximately $(6 \times 6 \mathrm{~cm})$ was developed by spotting $100 \mu \mathrm{L}$ of the bacteriocin sample $(1 \mathrm{mg} / \mathrm{mL})$ that was gently deposited at several spots on the silica gel plate under similar conditions mentioned in TLC-DB and was left for $30 \mathrm{~min}$ (at room temperature) for an evenly spread. Later, the TLC plate was placed face down, ensuring a proper contact on to the $M$. smegmatis $\left(10^{6} \mathrm{CFU} / \mathrm{mL}\right)$ inoculated agar layer in a petri dish for a period of 4-6 $\mathrm{h}$ to enable diffusion. Later the chromatogram was gently removed, and the agar plates were incubated at $37^{\circ} \mathrm{C}$ for $24 \mathrm{~h}$ and antibacterial activity was recorded. This experiment was done twice with duplicates.

\section{Agar diffusion DB}

The gels that were developed after $\mathrm{CBB} /$ silver staining in tricine SDS PAGE were thoroughly washed with $0.1 \%$ Tween 80 at room temperature. Subsequently one set of SDS-free gel was aseptically placed in LB broth $(0.7 \%$ agar, w/v) containing $M$. smegmatis $\left(10^{6} \mathrm{CFU} / \mathrm{mL}\right)$ as indicator and another set was placed under similar conditions with added trypsin $(1 \mathrm{mg} / \mathrm{mL})$. The plates were incubated at $37^{\circ} \mathrm{C}$ for $24 \mathrm{~h}$ and were observed for the presence of inhibition zones (Maricic \& Dawid, 2014; Saikat et al., 2014). This experiment was done twice with duplicates.

\section{Effect of enzymes and heat on bacteriocin}

Effect of hydrolytic enzymes was evaluated by taking each of 1:5 ratio of bacteriocin to Trypsin (pH-8.0; T-8918; Sigma), Proteinase K (pH-7.5; P-2308; Sigma), $\alpha$ - Chymotrypsin (pH-7.8; RM801; Himedia), Papain (pH-7.0; GRM058; Himedia) and Salivary amylase (pH-7.0; (Human Saliva in 1:9 of $0.85 \%$ saline solution) and the enzyme treated samples were incubated at $37^{\circ} \mathrm{C}$ for $24 \mathrm{~h}$. The bacteriocin untreated with enzyme was used as positive control and $30 \mu \mathrm{L}$ of DMSO alone is taken as blank. Thermal stability was examined by incubating bacteriocin for 10 min under moist heat treatment ranging from $40^{\circ} \mathrm{C}$ to $121^{\circ} \mathrm{C}$ by $10^{\circ} \mathrm{C}$ rise and samples unexposed to heat were taken as control. Residual activity of all the samples (each of $30 \mu \mathrm{L}$ ) tested for antimicrobial activity determined by agar well diffusion method with $M$. smegmatis $\left(10^{6} \mathrm{CFU} / \mathrm{mL}\right)$ as indicator. The assay was performed twice in triplicates.

\section{Inhibitory spectrum and Minimal Inhibitory Concentrations (MIC)}

Inhibitory spectrum assays were done by well diffusion assays, $30 \mu \mathrm{L}$ and $50 \mu \mathrm{L}$ of bacteriocin $(1 \mathrm{mg} / \mathrm{mL})$, was placed in the wells of the media overlaid with $100 \mu \mathrm{L}$ of gram positive and negative indicator microorganisms $\left(10^{6} \mathrm{CFU} / \mathrm{mL}\right)$ respectively, they were incubated at $37^{\circ} \mathrm{C}$ for $24 \mathrm{~h}$ and the antimicrobial activity was evaluated along with determination of the MIC values as described by Santhi \& Aranganathan (2019). All the assays were done in triplicates for a minimum of two independent experiments.

\section{Statistical Analysis}

All experimental results are expressed as means \pm standard error of the mean or standard deviation (SD) and the significant differences were examined by regression analysis by using [Microsoft 365 MSO (16.0.12827.20200) 32-bit] and One-way analysis of variance (ANOVA) by Tukey test (Post-hoc analysis) with SPSS 27.0. p-value $<0.05$ was considered statistically significant. Relative Percentage and residual activity were calculated in comparison to the Positive control values of the experiment performed.

\section{RESULTS AND DISCUSSION}

\section{Optimization and purification results}

Optimization of standard media and biophysical parameters had approximately increased the bacteriocin activity by $20 \%$ comparing to that of the crude. The growth kinetic pattern of $B$. subtilis (MK733983) suggested that the bacteriocin activity reached its maximum at the end of the exponential phase (figure 1). Further additional supplements like MEM amino acids or B complex vitamins had approximate enhancement of biomass by $43 \%$, total protein by $17 \%$ and antimicrobial activity by $33 \%$. Some of the common supplements like $\mathrm{CaCl} 2$, $\mathrm{MgSO} 4$ and multivitamins with trace elements had shown decreased bacteriocin activity (Tab 1). On elution with C18 SEP-PACK, specific activity of the bacteriocin increased as noted in Tab 2 and antimicrobial activity increased approximately by $33.3 \%$ with a ZOI of $20.17 \pm 0.07 \mathrm{~mm}$. 
Table 1 Optimization Results

\begin{tabular}{|c|c|c|c|}
\hline Optimization Factors & Range tested & $\begin{array}{c}\text { Optimal } \\
\text { Range }\end{array}$ & $\mathbf{Z O I}(\mathrm{mm})$ \\
\hline Standard Media & $\begin{array}{c}\text { Standard } \\
\text { constituents }\end{array}$ & - & 15 \\
\hline Peptone conc $(\%)$ & $0.5-2(0.25$ interval $)$ & 1.5 & $16.06 \pm 0.02$ \\
\hline Low $\mathrm{NaCl}$ conc $(\mathrm{g} / \mathrm{mol})$ & $\begin{array}{c}0.25-1.75(0.25 \\
\text { interval })\end{array}$ & 0.75 & $16.15 \pm 0.03$ \\
\hline High $\mathrm{NaCl}$ conc $(\mathrm{g} / \mathrm{mol})$ & $3,4 \& 5$ & 3 & $8.16 \pm 0.04$ \\
\hline Yeast \% & $\begin{array}{c}0.25-1(0.25 \\
\text { interval })\end{array}$ & 0.75 & $16.17 \pm 0.04$ \\
\hline Time course (Days) & $1-5$ (24h interval) & $24 \mathrm{~h}$ & $16.06 \pm 0.03$ \\
\hline $\mathrm{pH}$ & $6-8.5$ (0.5 interval) & 7 & $16.2 \pm 0.02$ \\
\hline Inoculum size (\%) & $1-6(1 \%$ interval $)$ & 1 & $18.08 \pm 0.02$ \\
\hline Temperature ${ }^{\circ} \mathrm{C}$ & $20-50\left(5^{\circ} \mathrm{C}\right.$ interval $)$ & 35 & $18.4 \pm 0.3$ \\
\hline $\begin{array}{l}\text { Physical parameters } \\
\text { Optimization }\end{array}$ & $\begin{array}{l}\text { Physical optimal } \\
\text { parameters }\end{array}$ & - & $18.4 \pm 0.3$ \\
\hline B complex vitamins $(\%)$ & $\begin{array}{c}0.5-3.5(0.5 \\
\text { interval })\end{array}$ & 2.5 & $20.12 \pm 0.02$ \\
\hline MEM amino acids (\%) & $1-2(0.25$ interval $)$ & 1 & $20.16 \pm 0.08$ \\
\hline $\mathrm{CaCl}_{2} \mathrm{~g} / \mathrm{mol}$ & $0.1-0.5$ (0.1interval) & 0.2 & $18.17 \pm 0.05$ \\
\hline $\mathrm{MgSO}_{4} \mathrm{~g} / \mathrm{mol}$ & $0.1-0.5$ (0.1 interval) & 0.1 & $15.22 \pm 0.02$ \\
\hline $\begin{array}{l}\text { Multivitamins with trace } \\
\text { elements }(\%)\end{array}$ & $1-2(0.25$ interval $)$ & $1 \%$ & $10.1 \pm 0.2$ \\
\hline Complete Optimization & With supplements & & $20.16 \pm 0.08$ \\
\hline
\end{tabular}

Legend: IMO-M. smegmatis; Optimal range represents the bacteriocin conc that was reported to exhibit highest antagonism towards IMO; ZOI - Zone of Inhibition in diamete on petri plates in $(\mathrm{mm})$ and values are means \pm standard deviation of triplicates $(\mathrm{p}<0.05)$.

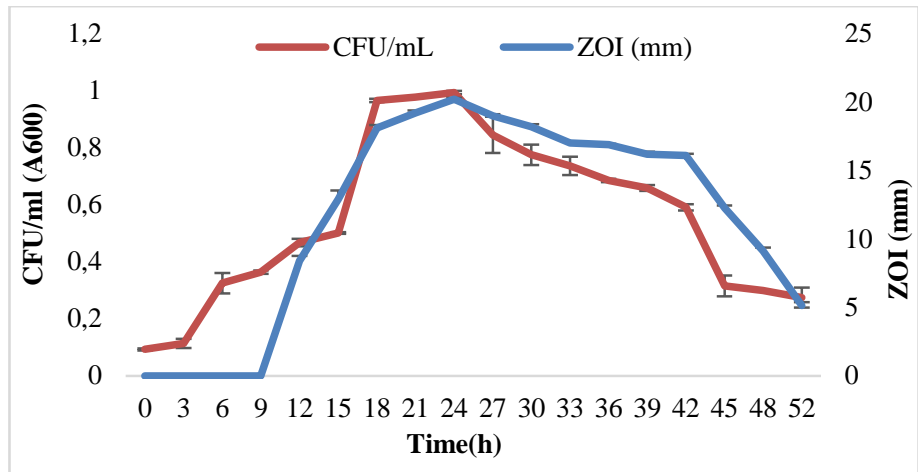

Figure 1 Growth of B. subtilis (MK733983) on incubation (h) and bacteriocin production. Cells growth at $\mathrm{A}_{600}$ and its bacteriocin production measured on the scale of its inhibition (mm) against imo, M. smegmatis. Values represented in the graph are means \pm standard deviation of triplicates $(\mathrm{p}<0.05)$.

\section{Characterization by tricine SDS-PAGE and Bio-profiling}

The bacteriocin showed migration as a single band with an estimated molecular weight to be below $14.3 \mathrm{kDa}$ on assessment with tricine SDS- PAGE. CBB staining showed better result comparing to silver staining (figure 2, Lane 1\&2). Figure 3 shows the TLC Chromatogram with a separation at $\mathrm{Rf}$ value of $0.85 \pm 0.005$ which fluoresce when viewed under $450-495 \mathrm{~nm} \& 380-450 \mathrm{~nm}$ and correspondingly a spot of clearing as an indicative of antibacterial activity against M. smegmatis was observed in its bioautogram. In contact bioautogram, the chromatogram taken showed a significant antibacterial activity inhibiting the growth of $M$. smegmatis, substantiating the ability of its antimicrobial entities to diffuse from complex substrates on contact and sustain its inhibitory action (figure 4). On agar diffusion DB of the gel band from PAGE, growth inhibition of the indicator (M. smegmatis) was observable in place of gel band and the gel band that was incubated in media treated with trypsin, showed growth of indicator organism, highlighting the proteolytic nature of the bacteriocin (Lane $3)$.

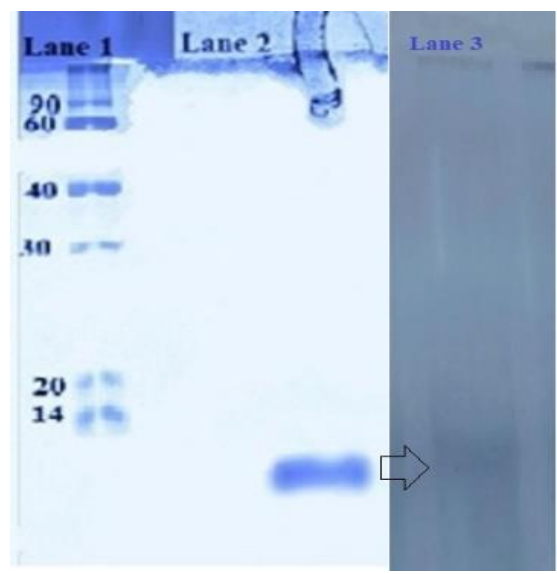

Figure 2 Tricine SDS-PAGE gels. LANE 1: Molecular Weight Standard; Lane 2 Migration of the bacteriocin; Lane 3: Trypsin digestion of the bacteriocin Gel Band.

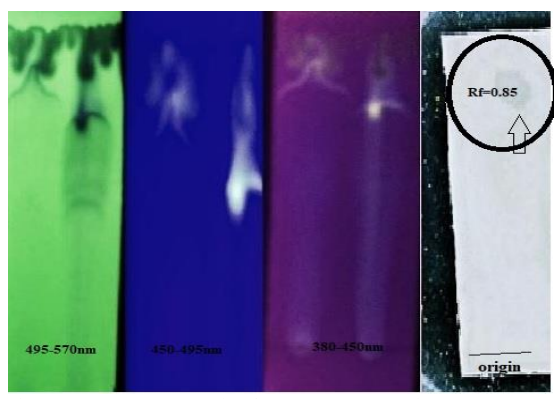

Figure 3 TLC Chromatograms and Bioautogram. Chromatograms recorded with 3 Filters Of TLC Viewers \& TLC Bioautogram shows microbial clearing observed at $\mathrm{Rf}=0.85 \pm 0.005(\mathrm{P}<0.05)$ with $\mathrm{IMO}$, M. Smegmatis

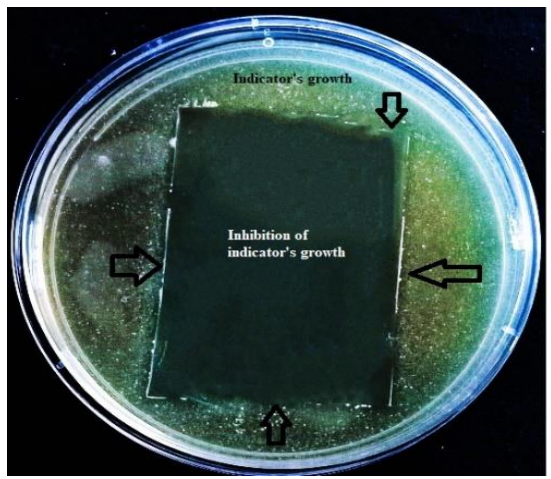

Figure 4 Contact Bioautogram. Bioautogram $(6 \times 6 \mathrm{Cm})$ showing the inhibition of IMO growth (M. Smegmatis).

\section{Effect of enzyme and heat}

Fig 5 shows the results of proteolytic enzymes effect on the bacteriocin, it showed a complete loss of activity with the Trypsin, $\alpha$-Chymotrypsin and Proteinase K. On the other hand, bacteriocin treated with salivary amylase did not show any loss of activity and treatment with Papain showed a residual activity of $8.1 \pm 0.07 \mathrm{~mm}(\mathrm{p}<0.05)$. compared to the positive control $(20.1 \pm 0.09 \mathrm{~mm})$. Bacteriocin showed a consistent thermostability up to $70^{\circ} \mathrm{C}$ and retained $\sim 59 \%$ activity at $100^{\circ} \mathrm{C}(\mathrm{Tab} 3)$.

\begin{tabular}{lcccccc}
\multicolumn{2}{l}{ Table 2 Purification of Bacteriocin } & & & \\
\hline Purification Steps & Volume Taken $(\mathrm{ml})$ & Total Protein $(\mathrm{mg})$ & Total Activity $(\mathrm{Au})$ & Specific Activity* & Recovery \% & Purification-Fold \\
\hline CFS & 100 & 12800 & 20500 & 1.6 & 100 & $1 \%$ \\
\hline Optimization & 100 & 15000 & 25000 & 1.66 & 121.90 & $1.03 \%$ \\
\hline C18 SEP-PACK & 80 & 900 & 8500 & 9.44 & 41 & $5.88 \%$ \\
\hline
\end{tabular}

Legend: * Specific activity is the ratio of total activity to that of total protein. 


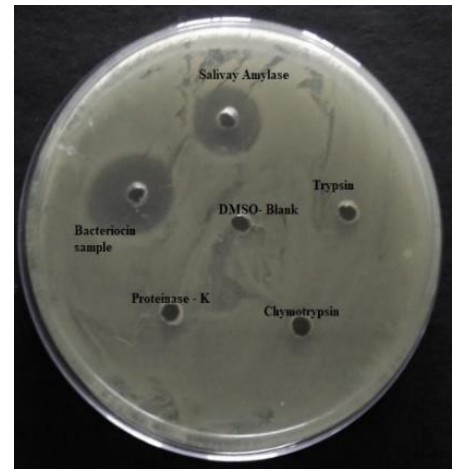

Figure 5 Effect of enzymes. IMO - M. smegmatis; ZOI of positive control (bacteriocin sample) - 20.1 $\pm 0.09 \mathrm{~mm}$, similarly with amylase treatment; No activity observed in blank/negative control (DMSO) or bacteriocin samples treated with Trypsin, Proteinase K, and $\alpha$ - Chymotrypsin.

Table 3 Thermostability of Bacteriocin

\begin{tabular}{lccc}
\hline S.NO. & Temperature $\left({ }^{\circ} \mathrm{C}\right)$ & ZOI $(\mathrm{mm})$ & Relative activity $(\%)$ \\
\hline 1 & Room Temperature & $20.17 \pm 0.07$ & 100 \\
\hline 2 & 40 & $20.15 \pm 0.05$ & 99.9 \\
\hline 3 & 50 & $20.14 \pm 0.15$ & 99.85 \\
\hline 4 & 60 & $20.05 \pm 0.05$ & 99.4 \\
\hline 5 & 70 & $20 \pm 0.05$ & 99.15 \\
\hline 6 & 80 & $17.7 \pm 0.25$ & 87.75 \\
\hline 7 & 90 & $14.8 \pm 0.6$ & 73.3 \\
\hline 8 & 100 & $12 \pm 0.17$ & 59.4 \\
\hline 9 & 121 & No inhibition & - \\
\hline
\end{tabular}

Legend: IMO-M. smegmatis; The bacteriocin is exposed to mentioned temperatures for 10 min; ZOI - Zone of inhibition by bacteriocin after heat exposure against IMO. values are means \pm standard deviation of triplicates $(\mathrm{p}<0.05)$

\section{Antibacterial spectrum and their MIC's}

The bacteriocin showed inhibitory action with both gram-positive and negative bacteria and their MIC values shown in Tab 4, revealed that the gram-negative bacteria needed more concentration of bacteriocin compared to that of grampositive bacteria, ranging $0.325 \pm 0.02-0.75 \pm 0.02 \mathrm{mg} / \mathrm{mL}(\mathrm{p}<0.05)$.

Table 4 Antibacterial spectrum with MIC values

\begin{tabular}{lllcc}
\hline S.NO. & $\begin{array}{l}\text { Indicator } \\
\text { Microorganism }\end{array}$ & $\begin{array}{l}\text { Gram's } \\
\text { character }\end{array}$ & ZOI $(\mathrm{mm})$ & $\begin{array}{c}\text { MIC } \\
(\mathrm{mg} / \mathrm{mL})\end{array}$ \\
\hline 1. & $\begin{array}{l}\text { Staphylococcus } \\
\text { aureus }\end{array}$ & Positive & $18.3 \pm 0.1$ & $0.325 \pm 0.02$ \\
\hline 2 & $\begin{array}{l}\text { Mycobacterium } \\
\text { smegmatis }\end{array}$ & Positive & $20.17 \pm 0.02$ & $0.35 \pm 0.004$ \\
\hline 3 & $\begin{array}{l}\text { Pseudomonas } \\
\text { aeruginosa }\end{array}$ & Negative & $19.5 \pm 0.39$ & $0.6 \pm 0.02$ \\
\hline 4 & $\begin{array}{l}\text { Klebsiella } \\
\text { pneumoniae }\end{array}$ & Negative & $16.03 \pm 0.5$ & $0.75 \pm 0.02$ \\
\hline 5 & Escherichia coli & Negative & $16.9 \pm 0.28$ & $0.7 \pm 0.02$ \\
\hline 6 & $\begin{array}{l}\text { Chromobacterium } \\
\text { violaceum }\end{array}$ & Negative & $16.58 \pm 0.23$ & $0.75 \pm 0.04$ \\
\hline
\end{tabular}

Legend: The bacteriocin taken per well for gram positive and negative IMOs is $30 \mu \mathrm{L}$ and $50 \mu \mathrm{L}(1 \mathrm{mg} / \mathrm{mL})$; MIC-minimal inhibitory concentrations. values are means \pm standard deviation of triplicates $(\mathrm{p}<0.05)$.

B. subtilis is a gram positive, aerobic and endospore forming rod shaped cells and are ubiquitous in nature. In the present investigation, a potential strain of $B$ subtilis (MK733983) isolated from ethnomedicinal plant origin was optimized for its bacteriocin production. The factors like time course, temperature and $\mathrm{B}$ complex vitamins showed a significant role in enhancing bacteriocin production. Rationale for escalatory and inhibitory effects of nutrient supplements on the bacteriocin producer must be further investigated. Growth kinetic study of $B$ subtilis shows that the potential entities of the bacteriocin was produced maximum between $18-24 \mathrm{~h}$

Generally aromatic, polycyclic compounds (Polycyclic aromatic Hydrocarbons $\mathrm{PaHs}$ ) with non-polar nature have higher $\mathrm{Rf}$ values and fluoresce when viewed under longer wavelengths, the bacteriocin in this study shows higher Rf value and fluoresce when viewed under 450-495nm \& 380-450nm and not under 495 $570 \mathrm{~nm}$, in this preliminary assessment and needs other confirmatory evaluation. A single band on tricine SDS-PAGE of the bacteriocin indicates that the sample deposited is a compound with minimal impurities. The presence of single band at this initial step of purification do not imply that the bacteriocin is pure, because of the possibility of presence of other sensitive molecules which are undetectable by the chosen method of experimentation.

Bio-profiling using Bio-autography is an association of planar chromatographic analyses with biological detection methods and known as effect-directed analyses (EDA) or Bioassay guided chromatography techniques and they are simple tools for characterizing antimicrobial properties of analyzed substances in minute quantities (Grzelak $\boldsymbol{e t}$ al., 2013). On the other hand, they are fast, accurate, inexpensive, and reliable methods to detect antimicrobial agents in a mixture of compounds, the bacteriocin demonstrated its ability to sustain activity in complex substrates in smaller quantities through TLC-DB. It also showed in-situ activity and its enzyme inhibition by trypsin affirming the proteinaceous nature by agar diffusion DB and its ability to diffuse by contact DB.

The bacteriocin treated with hydrolytic enzymes further reaffirmed its proteinaceous nature assuring its position as a GRAS (generally accepted as safe) protein along with its thermostability, as an added advantage (Hammami $\boldsymbol{e t}$ al. 2009) for its prospects as a bio-preservative. The improvement in thermostability of the bacteriocin on optimization and partial purification might be due to the increase of thermostable antimicrobial entities with conducive growth parameters. Bacteriocins from various microbes have generally exhibited a narrow inhibitory spectrum toward related producer strains (Klaenhammer, 1993). However, bacteriocins such as Thuricin 17 (Gray et al., 2006), Cerein 8A (Bizani et al., 2005), Gas 101 (Garima et al. 2018) have exhibited broad spectral inhibition. In agreement with the same, the bacteriocin in this study also showed antagonism towards certain critical and high prioritized gram positive and negative standard strains exhibiting its potential. $C$. violaceum is an emerging pathogen, widely studied for its quorum sensing mechanisms associated with the biofilm formation in many bacterial species (Batista \& Silva, 2017). The bacteriocin shows inhibition towards this emerging pathogen substantiating its probable capability to disrupt quorum sensing mechanisms, which must be further investigated. The plausible cause for more bacteriocin concentration to inhibit gram negative bacterial strains may be due to their unapt taxonomical characteristics.

Many bacteriocins from lactic acid bacteria and Bacillus species are proven competent natural preservatives that can inhibit the spoilage and spread of pathogenic bacteria in food (Gautam \& Sharma, 2009). They are emerging as potential surrogates and synergists to the chemical food preservatives with increase in demand for the natural bio-preservatives (Wayah \& Philip, 2018; Sarika et al., 2019) and are proficient to be considered as therapeutic agents (Christopher et al., 2012). There are very few reports proving that the bacteriocins are antiviral (Naruse $\boldsymbol{e t}$ al., 1990) and antimycobacterial (Sosunov et al., 2007) in nature. As per our knowledge, the results of the present study report the potential ethnomedicinal plant originated bacteriocin that has not only an effective antimycobacterial activity but antibacterial towards certain primal bacterial standard strains.

\section{CONCLUSION}

Currently multisectoral approach with divergent strategies are being developed globally to treat deleterious infections. Bacteriocins with their distinct features of selective toxicity towards wide microbial spectrum without developing resistance, are promising emerging alternatives. Their capacity to inhibit developed biofilms along with strong synergy with several antibiotics compared to conventional antibiotics are drawing attention as potential drug candidates for food and pharmaceutical industry. The significant characteristic features of the bacteriocin reported in this study has justified its ability to combat broad bacterial species and can be used as a precursor for the development of promising antimycobacterial / anti-bacterial drugs and as a bio-preservative. Further, characterization and mode of action, might enhance its efficacy and open new avenues for its wider application prospects

\section{Funding: Not Applicable}

Acknowledgements: The authors express their gratitude to Dr.Anusha (Department of Biochemistry, Jain (Deemed to-be) University, for assiatance with Tricine SDS PAGE.

Author contributions: The authors have contributed to the theme, design, practical work, data analysis and in writing the manuscript.

Conflict of interest disclosure: The authors declare that they have no conflict of interest.

\section{REFERENCES}

Batista, J.H., \& Silva, J.F. (2017). Chromobacterium violaceum Pathogenicity: Updates and Insights from Genome Sequencing of Novel Chromobacterium Species. Front. Microbiol, 8:2213. https://doi.org/10.3389/fmicb.2017.02213

Bizani, D., Motta, A.S., Morrissy, J.A., Terra, R., Souto, A.A., \& Brandelli. (2005). Antibacterial activity of cerein 8 A, a bacteriocin-like peptide produced by Bacillus cereus. INTERNATIONAL MICROBIOLOGY, 8:125-131. 
Demetrio, L.V., Juliana, J.M.P., Esperanza, C.C., \& Windell, L.R. (2016). Thin Layer Chromatography-Bioautography and Gas Chromatography-Mass Spectrometry of Antimicrobial Leaf Extracts from Philippine Piper betle L. against Multidrug-Resistant Bacteria. Evidence-Based Complementary and Alternative Medicine, 6:4976791-7. https://doi.org/10.1155/2016/4976791.

Garima, S., Shweta, D., Sanjay, G., \& Reema, G. (2018). Antibacterial Activity, Cytotoxicity, and the Mechanism of Action of Bacteriocin from Bacillus subtilis GAS10. Med Princ Pract, 27:186-192. doi: 10.1159/000487306

Gautam, N., Sharma, N. Bacteriocin: safest approach to preserve food products. Indian J Microbiol 49, 204-211 (2009). https://doi.org/10.1007/s12088-009 0048-3.

Giulian, G.G., Moss, R.L., \& Greaser, M. (1983). Improved methodology for analysis and quantitation of proteins on one-dimensional silver-stained slab gels. Anal. Biochem. 129:277-287. https://doi.org/10.1016/0003-2697(83)90551-1

Global priority list of antibiotic-resistant bacteria to guide research, discovery, and development of new antibiotics WHO report. 2017. Available: https://www.who.int/medicines/publications/global-priority-list-antibiotic-

resistant-bacteria/

Gray, E.J., Lee, K.D., Souleimanov, A.M., Di Falco, M.R., Zhou, X., Ly, A. Charles, T.C., Driscoll, B.T., \& Smith, D.L. (2006). A Novel Bacteriocin, Thuricin 17, produced by plant growth promoting rhizobacteria strain Bacillus thuringiensis NEB17: Isolation and Classification. J Appl Microbiol, 100(3):54554. https://doi.org/10.1111/j.1365-2672.2006.02822.x

Grzelak, E.M., Dziedzic, B.M., Choma, I.M., \& Pilorz, M. (2013). Thin Layer Chromatography-Bioautography and Gas Chromatography-Mass Spectrometry of Antimicrobial Leaf Extracts from Philippine Piper betle L. against MultidrugResistant Bacteria. Journal of AOA C International, 96:2. https://doi.org/10.5740/jaoacint.11-466

Hammami, Rhouma, A., Jaouadi, B., Rebai, A., \& Nesme, X. (2009) Optimization and biochemical characterization of a bacteriocin from a newly isolated Bacillus subtilis strain 14B for biocontrol of Agrobacterium spp. Strains. Lett Appl Microbiol, 48(2):253-60. https://doi.org/10.1111/j.1472 765X.2008.02524.X

Christopher, T.L., \& John, C.V. (2012). Development of Class IIa Bacteriocins as Therapeutic Agents. International Journal of Microbiology, 386410-13. https://doi.org/10.1155/2012/386410

Khalaf, H., Nakka, S.S., Sanden, C., Svard, A., Hultenby, K., Scherbak, N., Aili, D., \& Bengtsson, T. (2016). Antibacterial effects of Lactobacillus and bacteriocin PLNC8 on the periodontal pathogen Porphyromonas gingivalis. BMC Microbiology, 16:188. DOI https://doi.org/10.1186/s12866-016-0810-8

Khurram, M., Khan, M.A., Hameed, A., Abbas, N., Qayum, A., \& Inayat, H. (2009). Antibacterial Activities of Dodonaea viscosa using Contact Bioautography Technique. Molecules, 14:1332-41. https://doi.org/10.3390/molecules 14031332

Klaenhammer, T.R. (1993). Genetics of bacteriocins produced by lactic acid bacteria. FEMS Microbiol. Rev, 12:39-86. https://doi.org/10.1111/j.15746976.1993.tb00012.x

Lee, S.G., \& Chang, H.C. (2018). Purification and characterization of mejucin, a new bacteriocin produced by Bacillus subtilis SN7. LWT - Food Science and Technology, 87:8e15. http://dx.doi.org/10.1016/j.lwt.2017.08.044.

Lopez, P.M., Grimsey, E., Bourne, L., Mikut, R., \& Hilpert, K. (2017). Screening and Optimizing Antimicrobial Peptides by Using SPOT-Synthesis. Front. Chem, 5:25. https://doi.org/10.3389/fchem.2017.00025.e

Lowry, O.H., Rosebrough, N.J., Farr, A.L., \& Randall, R.J. (1951). Protein measurement with the Folin phenol reagent. J Biol Chem, 193(1):265-75.

Mahmoud, A., Ragaa, A., Asmaa, A., Sabha, M., \& Ghada, W. (2018). TLC Bioautographic Detection and Characterization of Antibacterial Compound from the Cyanobacterium Anabaena oryzae. AJB2T, 3(1):1-13. doi: https://doi.org/10.9734/AJB2T/2018/39097

Maricic, N., \& Dawid, S. (2014). Using the Overlay Assay to Qualitatively Measure Bacterial Production of and Sensitivity to Pneumococcal Bacteriocins. $J$ Vis Exp, 91-e51876. http://www.jove.com/video/51876.

Naruse, N., Tenmyo, O., Kobaru, S., Kamei, H., Miyaki, T., Konishi, M., \& Oki, T. (1990). Pumilacidin, a complex of new antiviral antibiotics. Production, isolation, chemical properties, structure, and biological activity. J Antibiot, 43(3):267-80. https://doi.org/10.7164/antibiotics.43.267

Park, Yong, S., Yang, Y.J., Kim, Y.B., Hong, J.H., \& Lee, C. (2002) Characterization of Subtilein, a Bacteriocin from Bacillus subtilis CAU131 (KCCM 10257). J Microbiol Biotechnol, 12(2): 228-34. https://scholarworks.bwise.kr/cau/handle/2019.sw.cau/25130.

Ramya, R., Ajay, G., Chalasani, R.L., \& Utpal, R. (2014). Antimicrobial Activity of Bacillus subtilis RLID 12.1. The Scientific World Journal, 968487-97. https://doi.org/10.1155/2014/968487.

Saikat, D., Moumita, G., Niloy, B., Ritu, K., \& Tarun, K. (2014). Bioautography and its scope in the field of natural product chemistry. Journal of Pharmaceutical Analysis, (2):75-84. https://doi.org/10.1016/j.jpha.2014.06.002

Santhi, S.S., \& Aranganathan, V. (2019). Bioprospecting of some ethnomedicinal plants for potential antimycobacterial bacteriocin like inhibitory substances (BLIS). Explor Anim Med Res, 9(2):180-187. ISSN 2319-247X (Online).
Sarika, A.R., Lipton, A.P. \& Aishwarya, M.S. (2019). Biopreservative Efficacy of Bacteriocin GP1 of Lactobacillus rhamnosus GP1 on Stored Fish Filets. Front Nutr. 6:29. https://doi.org/10.3389/fnut.2019.00029

Schagger, H., \& Jagow, G. (1987). Tricine-sodium dodecyl sulfatepolyacrylamide gel electrophoresis for the separation of proteins in the range from 1 to $100 \mathrm{kDa}$. Anal Biochem, 1:166(2):368-79. https://doi.org/10.1016/0003-2697(87)90587-2

Silva, C.C.G., Silva, S.P.M., Ribeiro, S.C. (2018). Application of Bacteriocins and Protective Cultures in Dairy Food Preservation. Front. Microbiol, 9:594 https://doi.org/10.3389/fmicb.2018.00594

Sosunov, V., Mischenko, V., Eruslanov, B., Svetoch, E., Shakina, Y., Stern, N., Majorov, K., Sorokoumova, G., Selishcheva, A., \& Apt, A. (2007). Antimycobacterial activity of bacteriocins and their complexes with liposomes. $J$ Antimicrob Chemother, 59(5):919-25. https://doi.org/10.1093/jac/dkm053

Tagg, J.R., \& McGiven, A.R. (1971). Assay system for bacteriocins. Appl Microbiol, 21(5): 943

Ventola, C.L. (2015). The antibiotic resistance crisis: part 1: causes and threats. $P$ $T, 40(4): 277-283$

Wayah SB and Philip K. Characterization, yield optimization, scale up and biopreservative potential of fermencin SA715, a novel bacteriocin from Lactobacillus fermentum GA715 of goat milk origin. Microb Cell Fact (2018) 17:125. https://doi.org/10.1186/s12934-018-0972-1.

World Health Organization, 2017. Antibacterial agents in clinical development: an analysis of the antibacterial clinical development pipeline, including tuberculosis. Geneva:; (WHO/EMP/IAU/2017.12). License: CC BY-NC-SA 3.0 IGO.

Zhang, J., Yang, Y., Yang, H., Bu, Y., Yi, H., Zhang, L., Han, X., \& Ai, L. (2018). Purification and Partial Characterization of Bacteriocin Lac-B23, a Nove Bacteriocin Production by Lactobacillus plantarum J23, Isolated from Chinese Traditional Fermented Milk. Front. Microbiol, 9:2165 doi: $10.3389 /$ fmicb.2018.02165 